\title{
Robert Cowen and Andreas Kazamias (eds.): International handbook of comparative education
}

\author{
Two volumes. Springer, Dordrecht, 2009, 1351 pp, \\ ISBN 978-1-4020-6402-9 (hbk), ISBN 978-1-4020-6403-6 (e-book)
}

\author{
Mark Bray
}

Published online: 27 April 2011

(C) The Author(s) 2011. This article is published with open access at Springerlink.com

This Handbook demands two hands. It is certainly weighty in a physical sense, comprising two thick volumes. It is also weighty in a conceptual sense and adds significantly to the field of comparative education. The editors are distinguished figures in the field, whose writings span many decades. They have assembled a wide range of contributors including many well-known authors; and their Handbook has both breadth and depth.

The field of comparative education is commonly paired with that of international education - to the extent to which Wilson (1994) described them as Siamese twins. The precise identities of these fields have been the focus of extensive debate over the decades. Concerning international education, Kaloyannaki and Kazamias in Chapter 3 of the Handbook note a variety of interpretations, including (a) study of the education of other peoples in other countries, (b) technical assistance to educational development in other countries, and (c) international cooperation in technical development through international organisations. On the whole, however, the Handbook eschews these domains. Even if comparative education and international education are Siamese twins, the Handbook focuses more on the comparative twin than on the international twin.

The question then, of course, is about the nature of the comparative twin. Although this is not a Handbook of Comparative and International Education, it is an International Handbook of Comparative Education. As such, a great deal of its content focuses on comparison at the national or supranational levels, and rather less addresses intra-national comparisons e.g. of provinces, districts, schools or pupils.

Nevertheless, the Handbook does reflect extensively on focus and evolution in the field. Cowen, for example, refers back to some of his earlier writings about "the unit ideas in comparative education" (p. 1285) and the value of comparing spaces,

\footnotetext{
M. Bray (西)

Comparative Education Research Centre, Faculty of Education, The University of Hong Kong,

Hong Kong, China

e-mail: mbray@hku.uk
} 
times, the state, educational systems, educated identities, social contexts, transfer, and praxis. Cowen also returns to his motif that one should also talk about comparative educations, in the plural. These, he suggests (p. 1285), include:

a 'comparative education' of solutions offered by agencies such as the OECD or the World Bank; a comparative education of international evaluation - IEA studies and PISA...; a 'comparative education' of the politically sanctified or politically correct dichotomised binaries (traditional/modern; developed/ developing; capitalist/socialist; East/West; North/South); and a specialist and good 'comparative higher education' literature.

Also exemplified in this book are contrasting (and evolving) traditions of the field in different parts of the world - the United Kingdom compared with the United States; China compared with Japan etc. Insofar as comparative education is mainly an academic field studied in universities, approaches undertaken in different countries are strongly shaped not only by scholarly traditions but also economic, political and other forces.

In structure, the Handbook is divided into eight sections, entitled:

1. The Creation and Re-creation of a Field;

2. Political Formations and Educational Systems;

3. The National, The International, and The Global;

4. Industrialisation, Knowledge Economies and Education;

5. Postcolonialism (assembled by Elaine Unterhalter rather than the two main editors);

6. Cultures, Knowledge and Pedagogies;

7. New Thinking; and

8. The Cutting Edge - Questioning the Future.

These headings give some flavour of the approaches. The first, seventh and eighth sections are dominated by reflection on the field as a field - its histories, identities, boundaries and emphases. The other five sections address particular themes. Some chapters are tied to continental foci (Africa, Europe, the former Soviet Union); others address pairs or triads of countries (Argentina and Brazil; China and Japan; Egypt, Lebanon and Turkey); a few address individual countries (England, Greece, India, Italy, Spain). Most address macro-level issues such as the role of the state, social justice, globalisation and economic development. Three are specifically about pedagogy, but only one is about (lifelong) learning. These emphases themselves reflect the field as represented in the journals and books explicitly devoted to comparative education.

In a concluding chapter, the editors reflect on what a Handbook can and cannot do. Part of the point of a Handbook, they observe (p. 1295), is looking backwards: "what has been done in this field of study, where are we up to?". This particular work makes a strong case for seeking further innovative ways of looking at the world in order to improve conceptual understandings. Some of these innovations are thematic, others concern units of comparison, and yet others involve listening to quiet voices to hear relatively inaudible perspectives. Handbooks, as the editors note, automatically invite criticisms that some themes are missing and that others 
are under-estimated. But such critiques, they add, are to be welcomed precisely because a Handbook is not a conclusion. A work of this type, the editors stress, "is not intended to freeze a field, to fix a canon, but to rehearse and then release a field of study... New comparative educations not imagined in this Handbook can - and will - be created".

With this in mind, the readers of this pair of volumes may indeed appreciate the editors and authors for their labours. The 80 chapters are not of course of uniformly excellent quality-which itself perhaps reflects the nature of the field. But the Handbook indeed achieves its goal of assessing the past and present of the field, and of suggesting future directions. It will serve as a lasting benchmark and reference, both for individual chapters and in its entirety.

Open Access This article is distributed under the terms of the Creative Commons Attribution Noncommercial License which permits any noncommercial use, distribution, and reproduction in any medium, provided the original author(s) and source are credited.

\section{Reference}

Wilson, D. N. (1994). Comparative and international education: Fraternal or Siamese twins? A preliminary genealogy of our twin fields. Comparative Education Review, 38(4), 449-486. 